
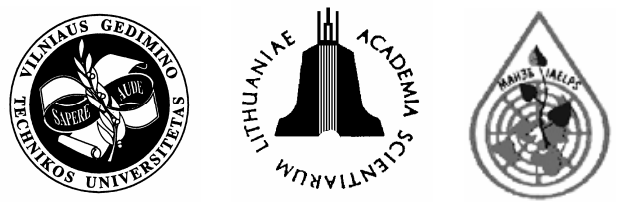

\title{
MODELLING OF COUPLED GROUNDWATER FLOW AND RADIONUCLIDE TRANSPORT IN CRYSTALLINE BASEMENT USING FEFLOW 5.0
}

\author{
Vaidotė Jakimavičiūtė-Maseliene் ${ }^{1}$, Jonas Mažeika ${ }^{2}$, Rimantas Petrošius ${ }^{3}$ \\ ${ }^{1,2,3}$ Institute of Geology and Geography, T. Ševčenkos g. 13, LT-03223 Vilnius, Lithuania. \\ E-mail:1 jakimaviciute@geo.lt,2mazeika@geo.lt, ${ }^{3}$ petrosius@geo.lt \\ Submitted 30 Mar 2006; accepted 18 May 2006
}

\begin{abstract}
The strategy of radioactive waste management of Lithuania provides for evaluating the possibilities of disposal of spent nuclear fuel and long-lived radioactive waste originated from Ignalina NPP in deep geological formations. The initial studies performed in Lithuania during 2001-2004 focused on screening of all potentially prospective geological formations as host formations. Since most information is available on crystalline basement, this formation was selected for the model case studies. Taking into account the assumptions (canister defect scenario proposed by Swedish experts and evaluated by LEI experts), groundwater flow and radionuclide (iodine-129 as mobile and long-lived one) transport modelling using computer code FEFLOW was performed according to geosphere conditions and parameters characteristic of the southern part of Lithuania $(0,8 \times 0,6 \times 0,52 \mathrm{~km}$ far-field block). The upward groundwater flow through defected canister located in tectonically damaged zone was simulated. The main results of calculations are the following: in the case of upward groundwater flow, the maximum I-129 volumetric activity in single tectonic fracture above defected canister will not exceed $1 \mathrm{~Bq} / \mathrm{l}$, and in the active water exchange zone, it is close to $10^{-2} \mathrm{~Bq} / \mathrm{l}$. These figures show that doses obtained by human recipient via aquatic pathway should be below the dose constraint $(0,2 \mathrm{mSv} / \mathrm{y})$. More complicated scenarios and assumptions should be investigated in future studies.
\end{abstract}

Keywords: spent nuclear fuel, geological repository, crystalline basement, groundwater, numerical modelling, finite elements.

\section{Introduction}

During the operation of Ignalina NPP spent nuclear fuel (SNF) is produced. Since the beginning of Ignalina NPP operation in 1983, all SNF and operational radioactive waste have been stored at the NPP site. Since May 1999, SNF, after being stored in water ponds inside the NPP buildings, has been removed from there, loaded into CASTOR RBMK-1500 or CONSTOR RBMK-1500 casks and transported to an interim storage facility in the industrial area of the NPP. SNF can be stored in these casks for at least 50 years. Due to the danger of exposure arising from long-lived radionuclides to humans and the environment, SNF is prohibited for disposal in the nearsurface repositories [1,2].

Several alternatives related to safe management and disposing of SNF are being analyzed for the future. They are a possibility of having a deep geological repository for SNF and long-lived radioactive waste in any SNFgenerating country, the possibilities of constructing a regional repository by joint efforts of several countries that generate or do not SNF, the possibilities of disposing of SNF in other countries, and the possibilities of extending the storage period in an interim storage for up to 100 and more years.

There is an international consensus that high-level and long-lived radioactive waste, first of all SNF, is best disposed of in deep geological repositories using a system of engineered and natural barriers [3]. It is a common opinion that there are few environments for which there exists evidence of stability over hundreds of thousands of years. Modern technology enables assessing old deep geological formations as the most obvious candidate environments.

No geological repository is in operation yet, however, repository projects in Finland, Sweden and USA have advanced to a stage at which decisions can be made to begin their construction [2]. Various types of geological formations are well investigated and can act as host rocks for a SNF repository. Since most information regarding deep geological formation in Lithuania is available on crystalline basement, this formation was selected for the model case studies [4-6].

On the basis of canister defect scenario evaluated by LEI experts, groundwater flow and radionuclide (iodine129 as mobile and long-lived one) transport modelling, using computer code FEFLOW, was performed in this particular study for geosphere conditions prevailing in the southern part of Lithuania.

\section{Outline of the problem of spent nuclear fuel}

The expected total amount of SNF produced in Ignalina NPP until 2010 is 21941 fuel assemblies [5]. Each 
fuel assembly contains approximately $111 \mathrm{~kg}$ of metal uranium, so the total mass of SNF that should be disposed of in the repository is about $2436 \mathrm{t}$. The radionuclide inventory in SNF will consist of actinides (uranium, plutonium isotopes, etc.), fission products (iodine, selenium, etc), and many activation radionuclides (a product of activation of metallic parts of fuel assembly). Most of radionuclides lie embedded in the fuel matrix of uranium dioxide for a very long time. A few fission products are relatively mobile. One of them is iodine-129 the inventory of which per canister in the model case study is assumed to be the same as in Swedish BWR fuel $\left(2,31 \mathrm{E}+09 \mathrm{~Bq},{ }^{129} \mathrm{I}\right.$ half life $1,57 \mathrm{E}+07$ years, decay rate $1,3974 \mathrm{E}-111 / \mathrm{s})$.

Repositories for disposal of SNF and high-level waste generally rely on a multi-barrier system to isolate waste from the biosphere. The multi-barrier system usually comprises a natural geological barrier and engineered barrier system [7]. The host rock types currently under investigation are salts (in either salt domes or bedded formations), granite and similar crystalline rocks, argillaceous rocks, tuff and basalt. The most investigated host rocks to date are crystalline rocks.

The Finnish government and local population first have recently approved a preferred site for SNF disposal in granite at Olkiluoto on the Baltic Coast. Sweden has focused onto two granite areas. Other countries that have considered granite-siting options include France, Switzerland, Spain and Canada.

The most developed Swedish concept for a deep geological repository involves encapsulating the fuel in cooper canisters with cast iron inserts, embedding each canister vertically or horizontally (two concepts, KBS-3V and $\mathrm{KBS}-3 \mathrm{H}$ ) and surrounding them with bentonite clay at a depth of about $500 \mathrm{~m}$ in the Swedish crystalline basement. In recent $\mathrm{KBS}-3 \mathrm{H}$ alternative is proposed socalled super-container, which consists of a perforated steel cylinder with highly compacted bentonite and one cooper canister inside [8].

The KBS-3H concept was chosen as a prototype in modelling case of repository in crystalline basement in Lithuania [4].

\section{Hydrogeological setting}

Hydrogeological framework of the southern Lithuanian region that includes the study area was outlined on the basis of the information summarized in recent geoscientific generalizations [6, 9-11].

The whole territory of Lithuania belongs to the Baltic artesian basin (BAB) that occurs in the East European platform. Groundwater of BAB occurs in the sedimentary cover and in the fractured rocks of the crystalline basement. The groundwater-forming process depends on the structural geological features as well as climatic conditions, relief and river drainage of the region.

Quaternary deposits (glacial till, various sand and silt) occur at the ground surface and form the uppermost part of geological section of the region. The total thickness of these deposits varies from 83 to $143 \mathrm{~m}$ (an average thickness is $119 \mathrm{~m}$ ). The smallest thickness is characteristic of the nor- thern part of the region. Quaternary deposits of maximal thickness occur in the highlands of the region.

There are six aquifers (shallow groundwater layer and five confined layers) in the Quaternary cover. Shallow (unconfined) groundwater occurs at $1 \mathrm{~m}$ depth in the lowlands and at more than $10 \mathrm{~m}$ depth in sandy elevations. Confined Quaternary aquifers occur in inter-glacial sands and gravels. Piezometric level and hydraulic properties of Quaternary aquifers are different and depend on the complexity of the geological structure. The groundwater of Quaternary aquifers is fresh (TDS $<1 \mathrm{~g} / \mathrm{l}$ ), its total hardness varies from 4 to $7 \mathrm{mg}$-ekv/l, and $\mathrm{pH}$ is about 7,5. Ions of hydrocarbonate and calcium prevail in the chemical composition of water. For modelling purpose, all Quaternary aquifers are considered as a unified aquifer system [6].

The Cretaceous aquifer consists of chalk, silt, and sand. The top of the aquifer dips from an altitude of $61 \mathrm{~m}$ a.s.l. to $-10 \mathrm{~m}$ b.s.l. The thickness of the aquifer varies from 30 to $105 \mathrm{~m}$. The hydraulic head of the aquifer varies between the altitudes of 150 and $155 \mathrm{~m}$ a.s.l. The specific yield varies from 0,1 to $2 \mathrm{l} / \mathrm{s}$, and permeability - from 1 to $260 \mathrm{~m}^{2} / \mathrm{d}$. Fresh groundwater prevails in the aquifer except several anomalies in the valley of the Nemunas river.

The Permian aquifer occurs mostly in the northern and northwestern parts of the region. It consists of fractured limestone and sandstone. The top of the aquifer occurs from a depth of $141 \mathrm{~m}$ to a depth of $244 \mathrm{~m}$. It dips to the west and southwest. The thickness of the aquifer reaches $20-25 \mathrm{~m}$. The hydraulic head occurs between the altitudes of 160 and $210 \mathrm{~m}$. The specific yield of the aquifer varies from 0,2 to $2,4 \mathrm{l} / \mathrm{s}$. Permeability varies between 2 and $366 \mathrm{~m}^{2} / \mathrm{d}$. The salinity of groundwater reaches $50 \mathrm{~g} / \mathrm{l}$. Sodium and chloride ions prevail in the hydrochemical composition of the water.

The Silurian-Upper and Middle Ordovician aquifer system occurs over the studied region except the southernmost edge. It consists of limestone and clay. The top of the aquifer occurs at a depth of 204 to $277 \mathrm{~m}$. The hydraulic head occurs at an altitude $150 \mathrm{~m}$ a.s.l. The lowest level is characteristic of the northern part and rises to the southeast. The specific yield of the aquifers varies from 0,002 to $0,296 \mathrm{l} / \mathrm{s}$, and permeability is less than $44 \mathrm{~m}^{2} / \mathrm{d}$. The salinity value of groundwater is low only near the boundaries of aquifer and rises up to $50 \mathrm{~g} / \mathrm{l}$ in the thicker part.

The Lower Ordovician - Cambrian aquifer system consists of limestone, clayey limestone and sandstone. The altitude of the aquifer top is varying from $150 \mathrm{~m}$ to $210 \mathrm{~m}$ b.s.l. It dips to the west. The hydraulic head varies between the altitudes of 80 and $150 \mathrm{~m}$ a.s.l. The specific yield of the aquifer varies from 0,035 to $0,25 \mathrm{l} / \mathrm{s}$, and permeability is less than $40 \mathrm{~m}^{2} / \mathrm{d}$. The salinity of the groundwater could be from $0,6 \mathrm{~g} / \mathrm{l}$ near the boundary of occurrence to more than $50 \mathrm{~g} / \mathrm{l}$ in the north.

The Lower Cambrian aquitard occurs in the northern and northeastern part of the region. It consists of argillite, sandstone and clay. The depth of the layer varies from 259 to $287 \mathrm{~m}$. The altitudes of occurrence are 
between $140 \mathrm{~m}$ (in the south) and $210 \mathrm{~m}$ (in the northwestern part of the region).

The Cambrian - Vendian aquifer system consists of sandstone and argillite. It occurs in the whole area of the region at a depth between 300 and $450 \mathrm{~m}$. The aquifer is dipping to the east. Its thickness reaches $100 \mathrm{~m}$ in the eastern part of the studied region. The specific yield of the aquifer varies between 0,006 and $0,25 \mathrm{l} / \mathrm{s}$, and permeability could be from 1 to $35 \mathrm{~m}^{2} / \mathrm{d}$. The aquifer has a strong hydraulic connection with the underlying Protherozoic-Archaean aquifer. Therefore, the hydraulic heads of these two systems are similar. It is about $20 \mathrm{~m}$ a.s.l. in the southwestern part and more than $110 \mathrm{~m}$ a.s.l. in the northeast. The salinity of the groundwater is low $(0,3-$ $0,5 \mathrm{~g} / \mathrm{l})$ where aquifer occurs at a smaller depth and can reach $100 \mathrm{~g} / \mathrm{l}$ deeper.

Sediments that were deposited at different stages of the basin evolution overlie the basement rocks. The crystalline rocks were exposed to denudation and weathering for different time intervals under various climatic conditions. Therefore, the upper part of the basement is weathered. The composition of the weathered crust varies significantly, that is related to the composition of the basement rocks and physical-chemical conditions.

The Proterozoic-Archaean aquifer occurs over the region. It consists of fractured crystalline rocks. Groundwater is accumulated in weathering and tectonic fractures. The aquifer occurs at a depth from $300 \mathrm{~m}$ to more than $600 \mathrm{~m}$. The permeability of the aquifer could reach $50 \mathrm{~m}^{2} / \mathrm{d}$, and the specific yield could be between 0,25 and $0,351 / \mathrm{s}$. The salinity of groundwater is lower than $1 \mathrm{~g} / \mathrm{l}$ in the southeast and could reach $100 \mathrm{~g} / \mathrm{l}$ in deep occurrence areas. Sodium and chloride ions prevail in the hydrochemical composition of groundwater [6].

A typical hydrogeological $2 \mathrm{~km}$ long section was chosen from the South Lithuanian region for assessment through modelling (Fig 1).

The site-specific for this section and generic parameters are given in Tables 1 and 2.

\section{Conceptual model}

According to the Swedish KBS-3H concept, variant MLH (Medium Long Hole) where canisters are proposed to be deposited in a 150-500 m long deposition hole on both sides of the transport tunnel, the evolution of one canister was considered [8]. A copper canister selected as a prototype for SNF from Ignalina NPP is composed of two components: an outer corrosion protective shell of copper and a cast iron insert with channels for the fuel half-assemblies in order to improve the mechanical strength. One canister can hold 32 RBMK-1500 fuel halfassemblies, and for Lithuanian disposal purposes, about 1400 canisters should be employed. A copper canister with $50 \mathrm{~mm}$ wall thickness should be made of oxygenfree copper with a low phosphorus content. A canister insert is cast of steel and will have a minimum wall thickness of $50 \mathrm{~mm}$. Preliminary data for a reference canister are $1050 \mathrm{~mm}$ in diameter and $4070 \mathrm{~mm}$ in length.

The chemical evolution of a damaged canister differs radically from that of an intact canister. Intruding water to a defected canister gives rise to several important chemical reactions, namely: corrosion of a cast-iron insert, corrosion of fuel claddings and other metallic parts, release of radionuclides in these parts, dissolution of the fuel matrix with release of radionuclides.

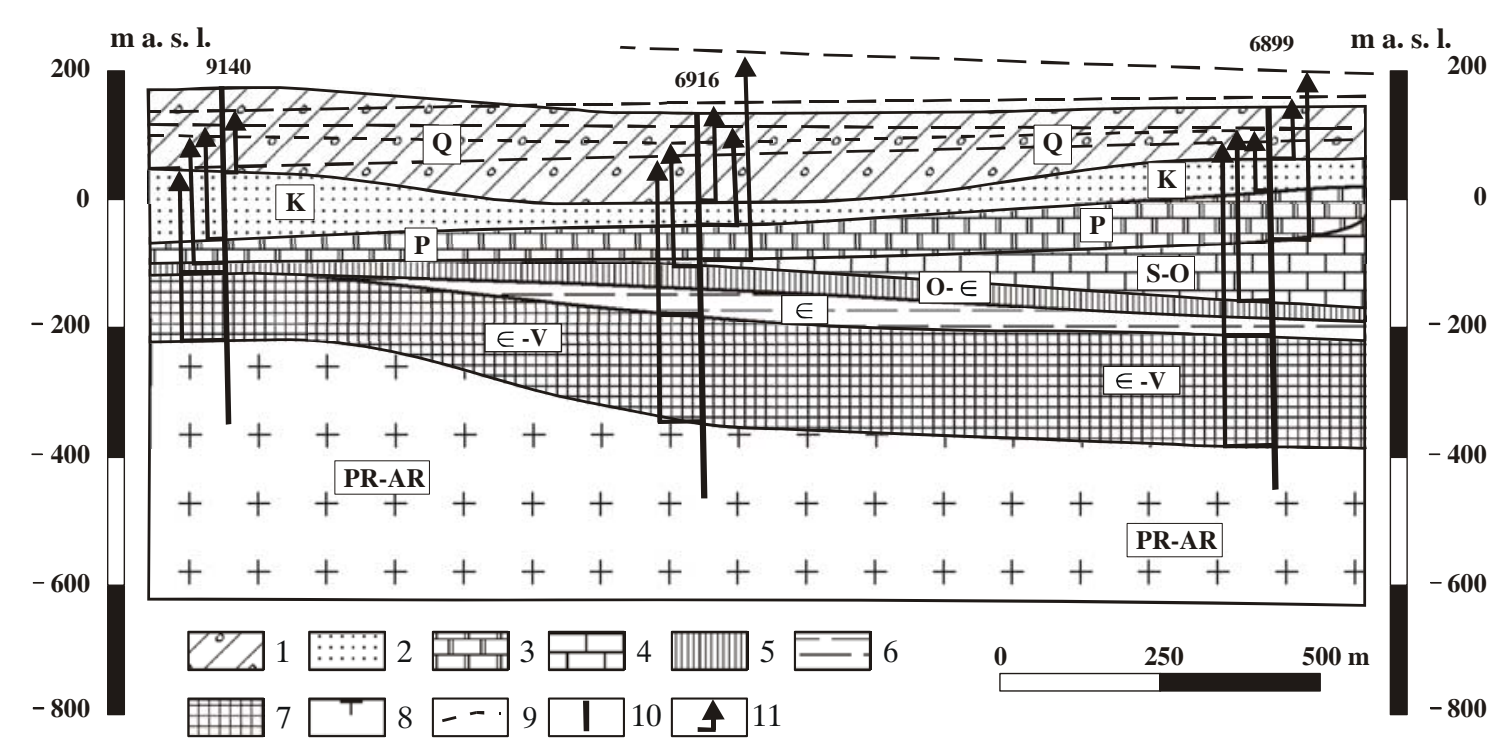

Fig 1. Hydrogeological cross-section: 1 - Quaternary deposits (glacial till, silt and various sands), 2 - Cretaceous (sandy deposits, silt and chalk), 3 - Permian (limestone and sandstone), 4 - Silurian-Upper-Middle Ordovician (limestone and clay), 5 - Lower Ordovician-Cambrian (limestone, clayey limestone and sandstone), 6 - Lower Cambrian (argillite, sandstone and clay), 7 - Cambrian-Vendian (sandstone and argillite), 8 - Proterozoic-Archaen (crystalline rocks), 9 - groundwater level, 10 - well, 11 - hydraulic head 
Table 1. Averaged hydrogeological parameters selected for simple modelling domain in the southern part of Lithuania $[6,9-12]$

\begin{tabular}{|c|c|c|c|c|c|c|c|c|c|}
\hline No & $\begin{array}{l}\text { Geological } \\
\text { formation }\end{array}$ & $\begin{array}{l}\text { Lithologi- } \\
\text { cal descrip- } \\
\text { tion } \\
\text { (prevai- } \\
\text { ling) }\end{array}$ & $\begin{array}{l}\text { Thick- } \\
\text { ness, } \mathrm{m}\end{array}$ & $\begin{array}{l}\text { Hydraulic } \\
\text { conducti- } \\
\text { vity, } \quad 10^{-4} \\
\mathrm{~m} / \mathrm{s}\end{array}$ & Porosity & $\begin{array}{l}\text { Den- } \\
\text { sity, } \\
\mathrm{kg} / \mathrm{m}^{3}\end{array}$ & $\begin{array}{l}\text { Henry } \\
\text { sorp- } \\
\text { tion } \\
\text { for }{ }^{129} \mathrm{I}\end{array}$ & $\begin{array}{l}\text { Longi- } \\
\text { tudinal } \\
\text { disper- } \\
\text { sivity, m }\end{array}$ & $\begin{array}{l}\text { Trans- } \\
\text { verse } \\
\text { disper- } \\
\text { sivity, m }\end{array}$ \\
\hline 1 & Quaternary & $\begin{array}{l}\text { Glacial } \\
\text { loam }\end{array}$ & 100 & 0,12 & 0,25 & 2000 & 2 & 0,01 & 0,001 \\
\hline 2 & Cretaceous & Sand & 100 & 0,23 & 0,35 & 2300 & 2,3 & 5 & 0,5 \\
\hline 3 & Permian & Anhydrite & 50 & 0,58 & 0,5 & 2980 & 2,98 & 0 & 0 \\
\hline 4 & $\begin{array}{l}\text { Silurian- } \\
\text { Ordovician }\end{array}$ & Limestone & 20 & 0,01 & 0,5 & 2600 & 2,6 & 5 & 0,5 \\
\hline 5 & $\begin{array}{l}\text { Ordovician- } \\
\text { Cambrian }\end{array}$ & Sandstone & 20 & 0,58 & 0,05 & 2700 & 2,7 & 5 & 0,5 \\
\hline 6 & Cambrian & Clay & 20 & $1,16 \cdot 10^{-6}$ & 0,13 & 2600 & 2,6 & 0,01 & 0,001 \\
\hline 7 & $\begin{array}{l}\text { Cambrian- } \\
\text { Vendian }\end{array}$ & Sandstone & 100 & 0,06 & 0,05 & 1800 & 1,8 & 5 & 0,5 \\
\hline 8 & \multirow[t]{2}{*}{$\begin{array}{l}\text { Proterozoic- } \\
\text { Archaean }\end{array}$} & $\begin{array}{l}\text { Weathered } \\
\text { rocks }\end{array}$ & 10 & $1,16 \cdot 10^{-3}$ & 0,01 & 2000 & 2 & 0,01 & 0,001 \\
\hline 9 & & $\begin{array}{l}\text { Crystalline } \\
\text { rocks }\end{array}$ & 100 & $1,16 \cdot 10^{-9}$ & 0,0038 & 2800 & 2,8 & 5 & 0,5 \\
\hline
\end{tabular}

Table 2. Parameters of single fracture representing tectonic fault zone [6]

\begin{tabular}{|l|c|c|}
\hline Parameters & $\begin{array}{l}\text { Crystalline } \\
\text { rocks (PR-AR) }\end{array}$ & $\begin{array}{l}\text { Sandstone } \\
(\mathrm{CM}-\mathrm{V})\end{array}$ \\
\hline Thickness, m & 1 & 1 \\
\hline $\begin{array}{l}\text { Hydraulic conductivity, } \\
10^{-4} \mathrm{~m} / \mathrm{s}\end{array}$ & 60 & 5 \\
\hline Porosity & 0,3 & 0,26 \\
\hline $\begin{array}{l}\text { Longitudinal dispersi- } \\
\text { vity, } \mathrm{m}\end{array}$ & 0,01 & 5 \\
\hline $\begin{array}{l}\text { Transverse dispersi- } \\
\text { vity, } \mathrm{m}\end{array}$ & 0,001 & 0,5 \\
\hline Henry sorption for ${ }^{129} \mathrm{I}$ & 2 & 1,8 \\
\hline Rock density, $\mathrm{kg} / \mathrm{m}^{3}$ & 2000 & 1800 \\
\hline
\end{tabular}

Following the results of near-field modelling [5], a simplified canister evolution is given for a canister defect scenario:

- One canister out of the total of 1400 will pass through quality inspection with a penetrating defect of $1 \mathrm{~mm}^{2}$ in size.

- 200000 years were chosen as a reasonable value for the time when the initial defect grows to a large one.

- After the defect becomes larger, the entire void in the canister at closure, approximately $0,5 \mathrm{~m}^{3}$, will be filled with water.

- Radionuclides released during the SNF dissolution process dissolve in water within the canister.

- If the concentration of radionuclide exceeds its solubility limit, they start to precipitate. Sorption on the internal parts of the canister is neglected.

- Radionuclides diffuse out through a defect hole.

- The buffer is fully saturated at the time when the release of radionuclides starts. Thus, radionuclides are transported through the bentonite buffer by diffusion mainly.

Radionuclides that reach the boundary of the bentonite buffer diffuse into the water flowing in the fracture intersecting the emplacement tunnel. Thus, radionuclides are transported to far-field and distributed in the hydrogeological system.

From several cases considered in detail in SR97 and referenced in [5], the most conservative case was selected in this study assuming that SNF is completely dissolved when a continuous water pathway is created (instant release fraction of $100 \%$ ).

A very simple conceptual model of radionuclide transport in the repository system, including far-field aquifers, is presented in Fig 2.

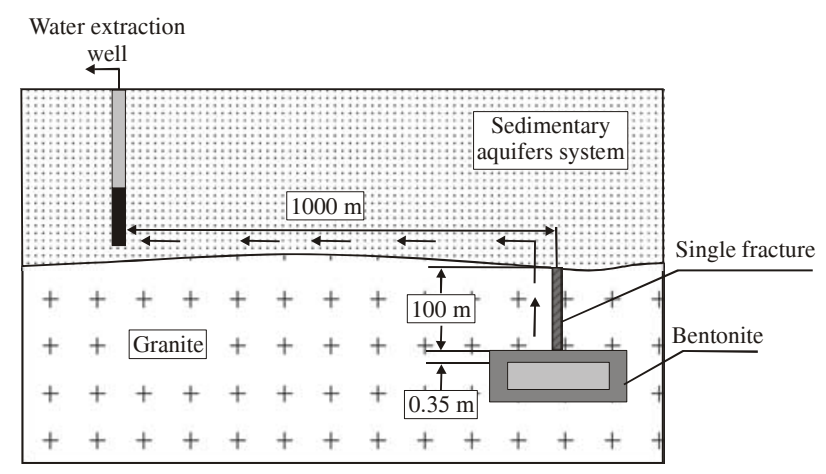

Fig 2. Conceptual model of radionuclide transport (not to scale) [5]

The simple conceptual model is adapted to the hydrogeological conditions of the study area demonstrated in the hydrogeological section (Fig 1).

It is conservatively taken that the canister is in the tectonic fault zone of crystalline basement. The groundwater washing the canister discharges into the upper aquifers. For enhancement of hydrodynamic effect it is taken that a productive well (yield value is $3000 \mathrm{~m}^{3} /$ day) is installed $363 \mathrm{~m}$ from the canister in the OrdovicianCambrian aquifer (sand).

The current understanding of solute migration processes in aquifers involves the following major important radionuclide migration mechanisms: advection in unsatu- 
rated and saturated zones, molecular diffusion, hydrodynamic dispersion and retardation [13, 14].

The migration of radionuclides from a repository toward the geosphere (aquifers) and eventually toward to the surface (or biosphere) can only start when the canister containing SNF has been defected and SNF has been dissolved by water and radionuclides have been transported away from the container through the engineered barriers surrounding them. In this study, the time for the mentioned processes is assumed to be 200000 years.

An additional component of the transport of radionuclides is their retardation by interactions with the solid phase. There are many types of possible interactions but the most common one is adsorption, particularly in the case of small particles (silt, clay, etc). Additional mechanisms may include chemical reactions (acid-base, redox, precipitation, etc) as well as reactions of a solute with organic molecules or with mineral colloids naturally present in groundwater. If radionuclides react with or absorb on such molecules or particles, they may not interact with the solid (no sorption) and be transported faster than expected. The issues of "facilitated" transport are particularly important in solutes with high colloid concentrations [15-17].

An estimated I-129 release rate through engineered barriers to far-field was taken from the study [5] as input function for 3D modelling of radionuclide transport in far-field (Fig 3).

\section{Computer code and numerical model}

The continuum approach is a standard to describe the fundamental processes of flow and transport in porous media [18]. The assumption of continuum implies that the main physical properties (velocity, pressure, concentration, etc) are continuously distributed in space and thus exist for any infinitely small material point.

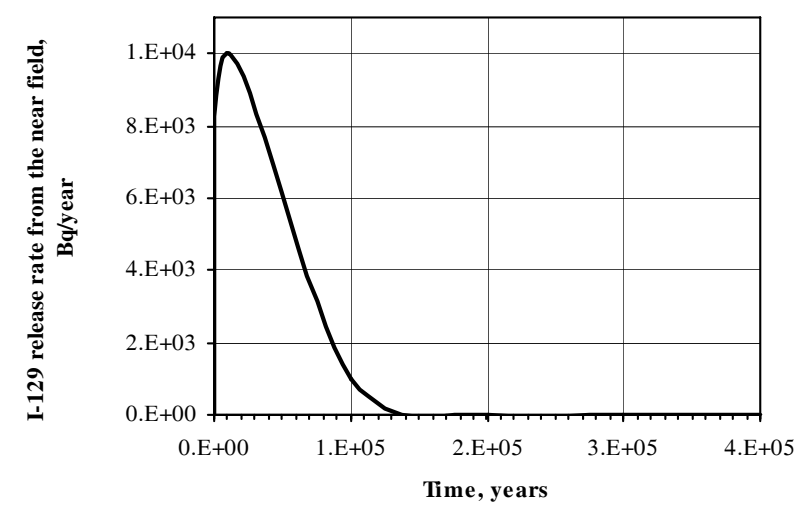

Fig 3. I-129 release rate from near-field starting after 200000 years after repository closure [5]

In most porous-media problems mass, motion and energy-related quantities can neither be measured nor solved at a microscopic level due to the geometric complexity of real geologic media. These difficulties are resolved by a transformation to the macroscopic level by averaging over volumes, leading to measurable and solv- able quantities for which the continuum assumption is then invoked. The related macroscopic equations are solved by numerical methods [19, 20]. Popular and powerful strategies are the finite element and finite volume method. Both methods have the same mathematical basis with weighted-integral formulation of the governing balance equations [18].

The finite element modelling has broad applications in various disciplines, including petroleum engineering (hydrocarbon-gas injection and recycling in gascondensate reservoirs), contaminant hydrogeology and geochemical engineering (contamination of groundwater aquifers and radioactive waste management in the subsurface).

Evaluation of radionuclide environmental effects on a long-term scale requires quantifying properly the hydrogeology of the area under consideration and then mass transport parameters. Constructing of a numerical model for groundwater flow permitted an integration of all the available pieces of site-specific information. However, mass transport parameters are usually absent for particular areas. In order to avoid impermissible uncertainties of simulation results a long-lived and very mobile radionuclide for illustrating the problem of radionuclide transport should be chosen.

The numerical model used in this study is based on three-dimensional finite-element code FEFLOW 5.0 which allows modelling groundwater flow and contaminant transport in layered three-dimensional system taking into account fracture phenomenon. The simulation system based on FEFLOW code models the flow and contaminant mass processes as coupled or separate phenomena [21]. It is based on physical conservation principles for mass, chemical species, linear momentum and energy in a transient and three-dimensional (if necessary, twodimensional) numerical analysis.

For three-dimensional (3D) and two-dimensional (2D) - vertical and axisymmetric, respectively - processes the representative model general equations are as follows $(i, j=1,2,3)$ :

$$
\begin{gathered}
S_{0} \frac{\partial h}{\partial t}+\frac{\partial q_{i}^{f}}{\partial x_{j}}=Q_{\rho}+Q_{E B}(C, T), \\
q_{i}^{f}=-K_{i j} f_{\mu}\left(\frac{\partial h}{\partial x_{j}}+\frac{\rho^{f}-\rho_{0}^{f}}{\rho_{0}^{f}} e_{j}\right) \\
\varepsilon R_{d} \frac{\partial C}{\partial t}+q_{i}^{f} \frac{\partial C}{\partial x_{i}}-\frac{\partial}{\partial x_{i}}\left(D_{i j} \frac{\partial C}{\partial x_{j}}\right)+ \\
\left(\varepsilon R \vartheta+Q_{p}\right) C=Q_{C},
\end{gathered}
$$

with constitutive equations

$$
\begin{gathered}
\rho^{f}=\rho_{0}^{f}\left[1+\frac{\bar{a}}{\left(C_{s}-C_{0}\right)}\left(C-C_{0}\right)\right], \\
h=\frac{p^{f}}{\rho_{0}^{f} g}+x_{i}, K_{i j}=\frac{k_{i j} \rho_{0}^{f} g}{\mu_{0}^{f}}, \\
\bar{a}=\left[\rho^{f}\left(C_{s}\right)-\rho_{0}^{f}\right] / \rho_{0}^{f},
\end{gathered}
$$




$$
\begin{gathered}
f_{\mu}=\frac{\mu_{0}^{f}}{\mu^{f}(C, T)}= \\
\frac{1+1,85 \omega_{\left(C=C_{0}\right)}-4,1 \omega_{\left(C=C_{0}\right)}^{2}+44,5 \omega_{\left(C=C_{0}\right)}^{3}}{1+1,85 \omega-4,1 \omega^{2}+44,5 \omega^{3}} . \\
\frac{1+0,7063 \varsigma-0,04832 \varsigma^{3}}{1+0,7063 \varsigma_{\left(T=T_{0}\right)}-0,04832 \varsigma_{\left(T=T_{0}\right)}^{3}}, \\
\varsigma=\frac{(T-150)}{100}, \omega=\frac{C}{\rho^{f}}, \\
R=1+\frac{(1-\varepsilon)}{\varepsilon} \chi(C), R_{d}=1+\frac{(1-\varepsilon)}{\varepsilon} \frac{[\chi(C) \cdot C]}{\partial C},
\end{gathered}
$$

which are to be solved for three primary variables $(h-$ hydraulic head; $q_{i}^{f}-$ Darcy velocity vector of fluid; $C$ concentration of chemical component or radionuclide).

The main governing parameters are: $\rho^{f}, \rho_{0}^{f}-$ fluid and reference fluid density, respectively; $\rho^{s}$ - solid density; $S_{0}-$ specific storage coefficient (compressibility); $K_{i j}-$ tensor of hydraulic conductivity; $e_{j}$ - gravitational unit vector; $f_{\mu}$ - constitutive viscosity relation function; $Q_{E B}-$ term of extended Boussinesq approximation; $R$ - specific retardation factor; $R_{d}$ - derivative term of retardation; $D_{i j}$ - tensor of hydrodynamic dispersion; $\delta_{i j}$ - Kronecker tensor; $v-$ decay rate $(\lambda$ is most conventional designation for radioactive decay rate); $\varepsilon-$ porosity; $Q_{x}$ - source/sink function of fluid $(x=\rho)$ and contaminant mass $(x=C) ; \bar{a}$ - fluid density difference ratio; $\bar{\beta}$ - fluid expansion coefficient; $C_{0}, T_{0}$ - reference values for concentration and temperature, respectively; $C_{s}$ - maximum concentration; $p^{f}$ - fluid pressure; $g$ gravitational acceleration; $k_{i j}$ - tensor of permeability; $\mu^{f}, \mu_{0}^{f}-$ dynamic viscosity and its reference value, respectively, of fluid; $\zeta$ - normalized temperature; $\omega-$ mass fraction; $D_{d}-$ molecular diffusion coefficient of fluid; $V_{q}^{f}-\sqrt{q_{i}^{f} q_{i}^{f}}-$ absolute Darcy fluid flux; $\beta_{L}$, $\beta_{T}$ - longitudinal and transverse dispersiveness, respectively, of chemical species; $\chi(C)$ - concentrationdependent adsorption function.

The relationships of retardation $R$ and $R_{d}$, respectively, can be summarized for different adsorption laws as follows [21]:

for Henry isotherm:

$$
R=\varepsilon(1-\varepsilon) K, R_{d}=\varepsilon+(1-\varepsilon) K,
$$

\section{for Freundlich isotherm:}

$$
R=\varepsilon+(1-\varepsilon) b_{1} C^{b_{2}-1}, R_{d}=\varepsilon+(1-\varepsilon) b_{1} b_{2} C^{b_{2}-1},
$$

for Langmuir isotherm:

$$
R=\varepsilon+(1-\varepsilon) \frac{k_{1}}{1+k_{2} C}, R_{d}=\varepsilon+(1-\varepsilon) \frac{k_{1}}{\left(1+k_{2} C\right)^{2}},
$$

where $K$ - Henry sorption coefficient; $b_{1}, b_{2}-$ Freundlich sorption coefficient and exponent, respectively; $k_{1}, k_{2}-$ Langmuir sorption coefficients.

The Henry sorption coefficient of the radionuclides is calculated as:

$$
K=k_{d} \rho^{s},
$$

where $k_{d}$ - distribution coefficient for particular radionuclide, $\mathrm{m}^{3} / \mathrm{kg} ; \rho^{s}$ - density of solid, $\mathrm{kg} / \mathrm{m}^{3}$.

From general equations, the horizontal model equations, which differ between confined and unconfined conditions and convective and divergence forms of contaminant transport equations, are derived. The governing model equations have to be supplemented by initial, boundary, and constraint conditions. There are many formulations of initial, boundary, and constraint conditions realized in FEFLOW. For the tensors of conductivity and transmissivity, anisotropy is to be taken into account in FEFLOW as well [21].

A comparatively simple and conservative (in terms of groundwater flow formulation) numerical model was worked out on the basis of a conceptual model (Table 3).

Table 3. Features of numerical model for the domain of southern Lithuania

\begin{tabular}{|l|l|l|l|}
\hline Problem class & Combined flow and mass transport model & Vertical exaggeration & $1: 1$ \\
\hline Time class & $\begin{array}{l}\text { Transient (unsteady) flow, transient (unsteady) mass trans- } \\
\text { port }\end{array}$ & Problem measure & $877,67 \mathrm{~m}$ \\
\hline Time stepping scheme & Fully implicit with constant time steps & Number of layers & 11 \\
\hline Upwinding & Full up winding & Number of slices & 12 \\
\hline Number of time steps & 50 & Type & Saturated \\
\hline Length of time step & $7.305 \cdot 10^{6} \mathrm{~d}$ & Dimension & Three-Dimensional \\
\hline Error tolerance & $1 \cdot 10^{-3}$ applied to Euclidian $\mathrm{L}_{2}$ integral (RMS) norm & Element type & 6-noded triangular prism \\
\hline $\begin{array}{l}\text { Maximum number of itera- } \\
\text { tions per time step }\end{array}$ & 12 & Mesh elements & 56232 \\
\hline Adaptive mesh error & $1 \cdot 10^{-2}$ & Mesh nodes \\
\hline A posteriori error estimator & Onate-Bugeda algorithm & Mesh optimization & Not done \\
\hline Velocity approximation & $\begin{array}{l}\text { Improved consistent velocity approximation (by Frolkovic- } \\
\text { Knabner algorithm) applied to linear elements with local } \\
\text { smoothing }\end{array}$ & Aquifers \\
\hline Form of transport equation & Convective & Projection \\
\hline Solver & Iterative equation solver & Adsorption law \\
\hline
\end{tabular}


Once calibrated, the model was used to predict radionuclide transport within groundwater and a potential effect to the environment. The model is virtually rather conservative and constructed in such a way as to imitate a greater migration of radionuclides to aquifers than it could be possible under the chosen geological conditions. The defected canister is installed in the top part of the crystalline basement, though, following the conceptual design, it should be at a depth of $100 \mathrm{~m}$.

\section{Discretization, parameterization, initial, boundary and constraint conditions}

Flow in all the aquifers of the numerical model is attributed to 11 layers and represented by $3 \mathrm{D}$ finite-element grid of 56232 mesh elements as shown in Fig 4.

The vertical discretization of the model and its parameter values are based on the data presented in Fig 1 and Tables 1 and 2. Vertical discretization of the model in terms of boundary conditions is shown in Tables 4 and 5.

For a numerical model, the created layers are adjusted to the geometry of lithological bodies. In the first simple model approach parameters are assumed to be constant within the whole modelling domain, e g each layer consists of one zone. For a brief illustration of groundwater flow modelling features, a modelled hydraulic head distribution in modelling layer 9 is given which corresponds to crystalline rocks (Fig 5).

By collecting additional hydrogeological information and during further model calibration, the number and outline of zones should be increased to minimize the difference between computed and measured or expected heads at observation points.

The default initial conditions of the hydraulic head and contaminant mass $(0 \mathrm{~Bq} / \mathrm{l})$ are used for this model.

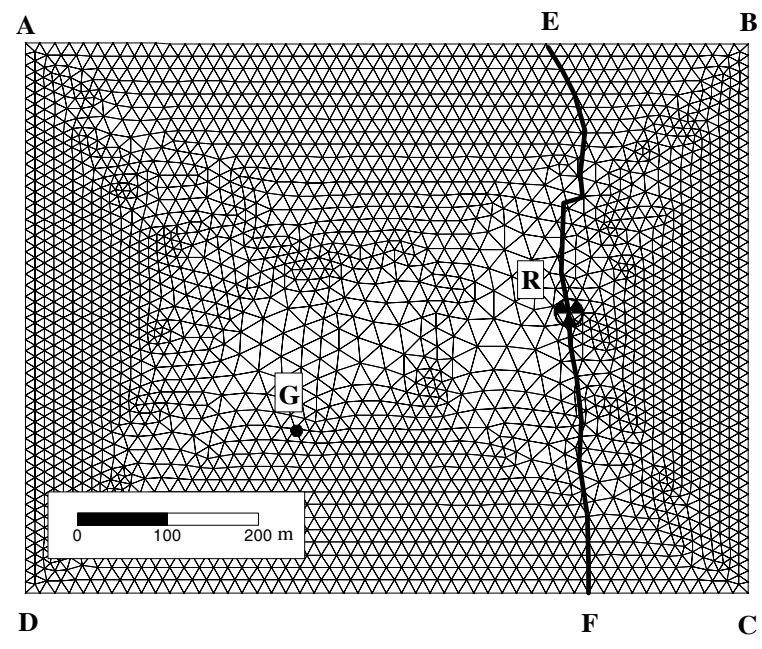

Fig 4. Finite-element grid used for the model domain of southern Lithuania (see Table 4)

\section{Model calibration and sensitivity analyses}

Model calibration by many repeated runs is routine in numerical simulation [22, 23].

Model calibration as practiced in this study is a process by which the structure and parameters of a nu- merical model are progressively changed in an iterative manner to obtain an acceptable match between observed or expected and computed hydraulic heads and departing as little as possible from the original conceptual model. In addition to fitting hydraulic heads, calibration was based on the following criteria: computed water levels should always stand below the topographic surface; estimated hydraulic conductivities should be consistent with conductivities derived from available hydrogeological data; spatial patterns of parameters should be consistent with available geological information. A direct experimental substantiation of mass transport is impossible because tracer experiments with long-living mobile radionuclides (I-129) are hardly validated, and the process of largescale radionuclide transport is very long-lasting.

Table 4. Flow boundary conditions for the model domain of southern Lithuania after model calibration (see Fig 4)

\begin{tabular}{|c|c|c|c|}
\hline $\begin{array}{c}\text { Section } \\
\text { or point } \\
\text { (layer) }\end{array}$ & Type & Value & Comment \\
\hline $\begin{array}{c}\mathrm{A}-\mathrm{B} \\
(1-11)\end{array}$ & - & - & $\begin{array}{c}\text { Unspecified } \\
\text { (impervious) } \\
\text { for all } 11 \\
\text { layers }\end{array}$ \\
\hline $\begin{array}{c}\mathrm{B}-\mathrm{C} \\
(1-11)\end{array}$ & $\begin{array}{l}\text { Dirichlet } \\
\left(1^{\text {st }} \text { kind }\right)\end{array}$ & $\begin{array}{l}h_{1}=155 \mathrm{~m} ; \\
h_{2}=154 \mathrm{~m} ; \\
h_{3}=153 \mathrm{~m} ; \\
h_{4}=152 \mathrm{~m} ; \\
h_{5}=151 \mathrm{~m} ; \\
h_{6}=150 \mathrm{~m} ; \\
h_{7}=149 \mathrm{~m} ; \\
h_{8}=148 \mathrm{~m} ; \\
h_{9}=147 \mathrm{~m} ; \\
h_{10}=147 \mathrm{~m} ; \\
h_{11}=146 \mathrm{~m}\end{array}$ & $\begin{array}{c}\text { Pervious } \\
\text { boundary } \\
\text { (influx) }\end{array}$ \\
\hline $\begin{array}{c}\mathrm{C}-\mathrm{D} \\
(1-11)\end{array}$ & - & - & $\begin{array}{c}\text { Unspecified } \\
\text { (impervious) } \\
\text { for all } 11 \\
\text { layers }\end{array}$ \\
\hline $\begin{array}{c}\mathrm{D}-\mathrm{A} \\
(1-11)\end{array}$ & $\begin{array}{l}\text { Dirichlet } \\
\left(1^{\text {st }} \text { kind }\right)\end{array}$ & $\begin{array}{l}h_{1}=130 \mathrm{~m} ; \\
h_{2}=131 \mathrm{~m} ; \\
h_{3}=132 \mathrm{~m} ; \\
h_{4}=133 \mathrm{~m} ; \\
h_{5}=134 \mathrm{~m} ; \\
h_{6}=135 \mathrm{~m} ; \\
h_{7}=136 \mathrm{~m} ; \\
h_{8}=137 \mathrm{~m} ; \\
h_{9}=138 \mathrm{~m} ; \\
h_{10}=138 \mathrm{~m} ; \\
h_{1 I}=139 \mathrm{~m}\end{array}$ & $\begin{array}{l}\text { Pervious } \\
\text { boundary } \\
\text { (outflow) }\end{array}$ \\
\hline $\begin{array}{c}\text { E-F } \\
(7-11)\end{array}$ & $\begin{array}{l}\text { Dirichlet } \\
\left(1^{\text {st }} \text { kind }\right)\end{array}$ & $h_{7-11}=147 \mathrm{~m}$ & $\begin{array}{c}\text { Pervious } \\
\text { boundary } \\
\text { (influx into } \\
\text { fracture repre- } \\
\text { senting tec- } \\
\text { tonic fault } \\
\text { zone) }\end{array}$ \\
\hline G(5) & ( $4^{\text {th }}$ kind $)$ & $\begin{array}{c}Q_{\rho}^{w}=3000 \\
\mathrm{~m}^{3} / \mathrm{d}\end{array}$ & $\begin{array}{l}\text { Pumping rate } \\
\text { of single well }\end{array}$ \\
\hline
\end{tabular}


Table 5. Boundary conditions for contaminant mass transport for the convective form

\begin{tabular}{|c|c|c|c|c|}
\hline \multirow{2}{*}{$\begin{array}{l}\text { Point } \\
\text { (layer) }\end{array}$} & \multirow[t]{2}{*}{ Type } & \multicolumn{2}{|l|}{ Value } & \multirow[t]{2}{*}{ Comment } \\
\hline & & years & $\mathrm{Bq} / \mathrm{l}$ & \\
\hline \multirow{6}{*}{$\begin{array}{l}\mathrm{R} \\
(10)\end{array}$} & \multirow{6}{*}{$\begin{array}{l}\text { Dirichlet } \\
\left(1^{\text {st }} \text { kind }\right) \text {; } \\
\text { time- } \\
\text { varying } \\
\text { function } \\
C\left(x_{i}, t\right)= \\
C_{1}^{R}(t)\end{array}$} & $<10000$ & 0 & \multirow{6}{*}{$\begin{array}{l}\text { Release } \\
\text { from reposi- } \\
\text { tory (de- } \\
\text { fected } \\
\text { canister) to } \\
\text { receiving } \\
\text { cell with } \\
\text { dimensions } \\
\text { of } 12 \times 12 \times \\
1,85 \mathrm{~m}\end{array}$} \\
\hline & & $\begin{array}{l}10000- \\
100000\end{array}$ & 3081 & \\
\hline & & $\begin{array}{l}100000- \\
200000 \\
\end{array}$ & 308 & \\
\hline & & $\begin{array}{l}200000- \\
300000\end{array}$ & 3,1 & \\
\hline & & $\begin{array}{l}300000- \\
400000\end{array}$ & 1,5 & \\
\hline & & $>400000$ & 0 & \\
\hline
\end{tabular}

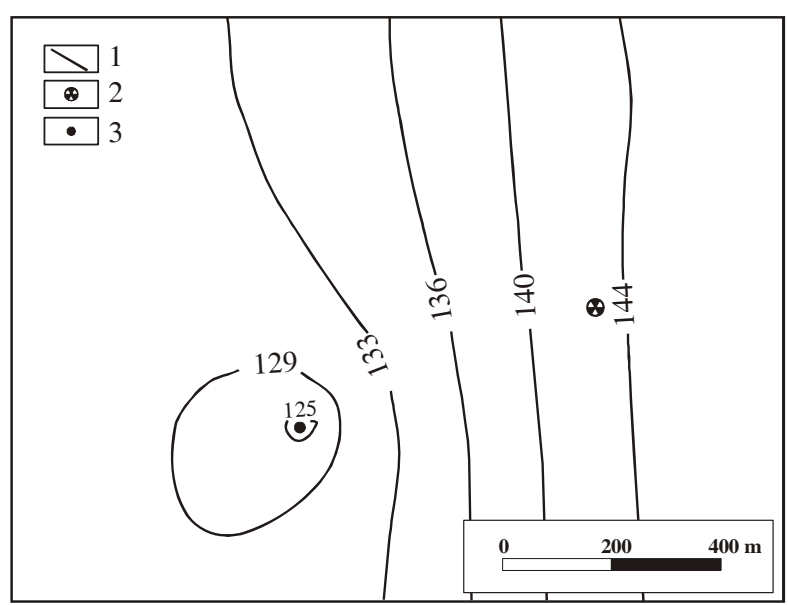

Fig 5. Simulated hydraulic head of layer 9 representing crystalline rocks after 40000 years: 1 - isoline of hydraulic head, $\mathrm{m}$ a.s.l., 2 - repository, 3 - pumping well

The parameters of relevance under far-field flow conditions routinely include hydraulic conductivity $(K)$, areal recharge, hydraulic heads $(h)$ specified along boundaries, dispersivity parameters $\left(\beta_{L}, \beta_{T}\right)$. Areal recharge was assumed to be uniform throughout the study area $\left(1,4 \cdot 10^{-4} \mathrm{~m} / \mathrm{d}\right)$.

A sensitivity analysis was performed to (a) quantify uncertainty in the estimated parameters and that of the parameters that remained fixed during calibration, and (b) evaluate the effect of some hypotheses of the conceptual model (for example, influence of a pumping well). The sensitivity of the model with respect to a given parameter was evaluated by performing calibration runs in which this parameter was assigned a fixed value within a plausible interval, while the rest of the model parameters were estimated. Sensitivity analyses were carried out using the final structure of the model, and its sensitivity was tested for (a) hydraulic conductivities of all the layers and for (b) dispersivity of all the layers (Figs 6 and 7).

For sensitivity analysis, runs of the model were made for four sets of hydraulic conductivity: 1 - normal hydraulic conductivity corresponding to the values of Table 1; 2 - normal conductivity increased by one order of magnitude; 3 - normal conductivity increased by two orders of magnitude; 4 - normal conductivity decreased by one order of magnitude. The change of volumetric
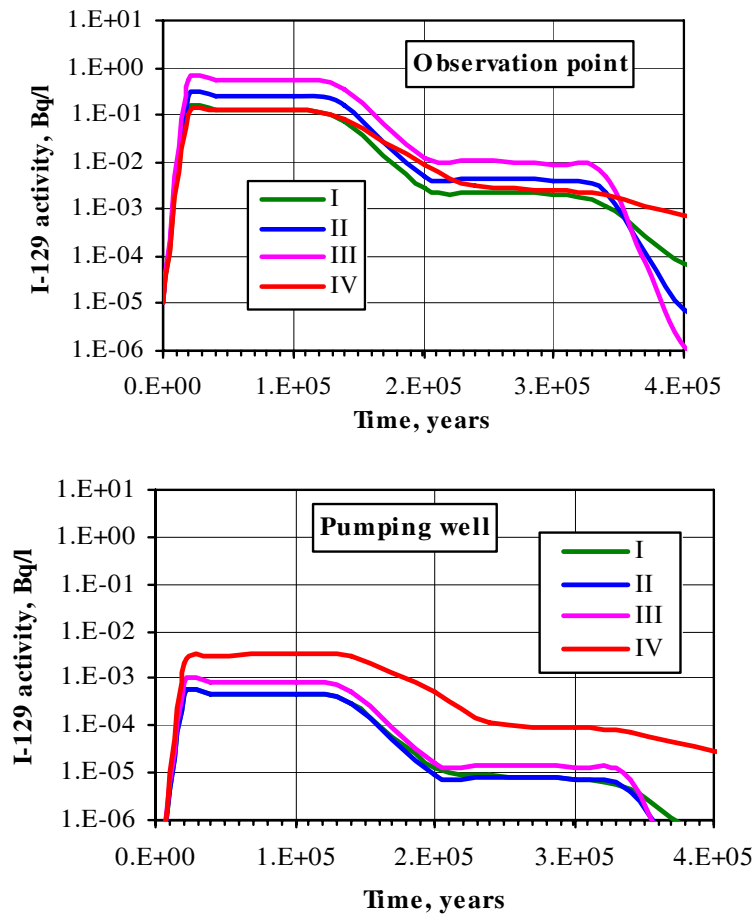

Fig 6. Computed temporal distributions of ${ }^{129}$ I volumetric activity in groundwater for different sets of hydraulic conductivity values (I - normal hydraulic conductivity; II - normal conductivity increased by one order of magnitude; III - normal conductivity increased by two orders of magnitude; IV - normal conductivity decreased by one order of magnitude)
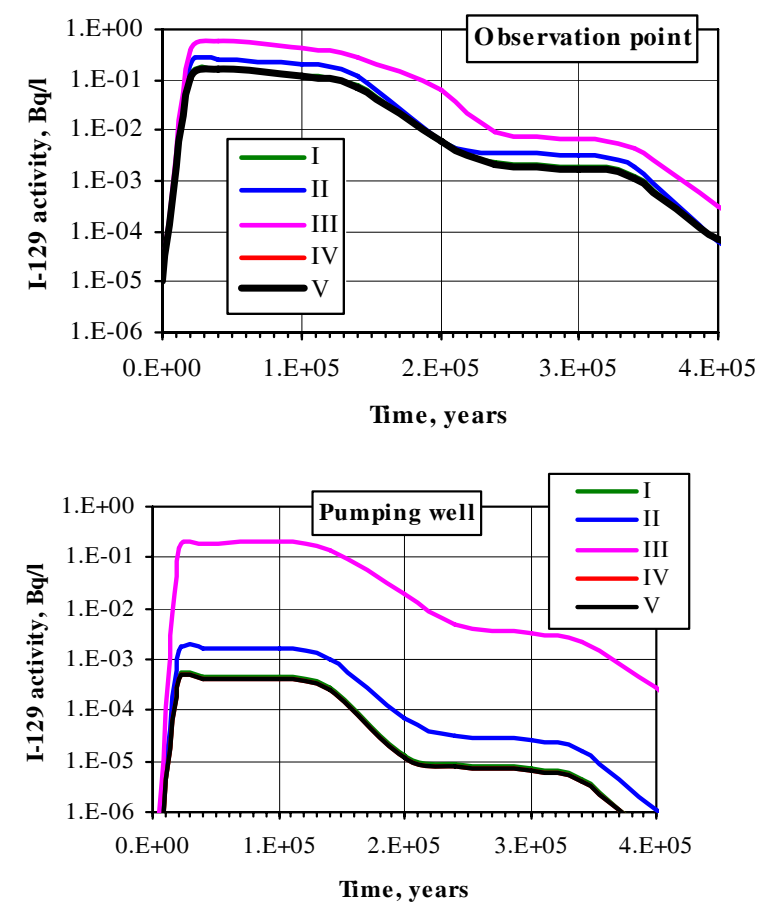

Fig 7. Computed temporal distributions of ${ }^{129}$ I volumetric activity in groundwater for different sets of hydraulic dispersivity values (I - normal dispersivity; II - normal dispersivity increased by one order of magnitude; III -normal dispersivity increased by two orders of magnitude; IV - normal dispersivity decreased by one order of magnitude; $\mathrm{V}$ - zero dispersivity) 
activity of I-129 in groundwater for a period of 0 to $10^{6}$ years was reconstructed at an observation point (layer $9-$ crystalline rocks, about $90 \mathrm{~m}$ from repository) and in a pumping well (layer 5 - sandstone, $363 \mathrm{~m}$ from a repository).

The volumetric activity of I-129 in the groundwater at an observation point close to the defected canister did not differ in more than one order of magnitude throughout the whole modelled period. The highest I-129 volumetric activity occurred when the normal conductivity increased by two orders of magnitude. Peak activity value in all the cases did not exceed $1 \mathrm{~Bq} / \mathrm{l}$. The volumetric activity of I-129 in the groundwater of a pumping well more remote to the defected canister did not differ in more than one order of magnitude throughout the whole modelled period either. The highest I-129 volumetric activity occurred when the normal conductivity decreased by one order of magnitude. Peak activity value in all the cases did not exceed $10^{-2} \mathrm{~Bq} / \mathrm{l}$.

For sensitivity analysis, runs of the model were made for five sets of longitudinal and transverse dispersivity parameters: 1 - normal dispersivity corresponding to the values of Table 1;2-normal dispersivity increased by one order of magnitude; 3 - normal dispersivity increased by two orders of magnitude; 4 - normal dispersivity decreased by one order of magnitude; 5 - zero dispersivity. The change of volumetric activity of I-129 in groundwater during the period from 0 to $10^{6}$ years was reconstructed at the same observation point (layer 9 crystalline rocks, about $90 \mathrm{~m}$ from a repository) and in a pumping well (layer 5 - sandstone, $363 \mathrm{~m}$ from a repository). The volumetric activity of I-129 in the groundwater at an observation point close to the defected canister in all the cases did not differ in more than one order of magnitude throughout the whole modelled period. Actually calculation results are the same in most of the cases except higher values when the normal dispersivity increased by two orders of magnitude. The volumetric activity of I-129 in the groundwater of a pumping well more remote to the defected canister did not differ in more than one order of magnitude throughout the whole modelled period either except the higher values when the normal dispersivity increased by two orders of magnitude.

The calibrated model especially in the pumping well area was very sensitive to changes in dispersivity parameters, namely, in the region of very high dispersivity values. The calibrated model in closer to a release point zone was less sensitive to changes in dispersivity parameters. On the other hand, model results for the two cases were not very sensitive to small or even large changes in the hydraulic conductivities. Therefore, the calibrated model was not very sensitive to errors in the hydraulic conductivity estimations.

\section{Spatial distribution of contamination plume}

Computer program FEFLOW enables spatial and temporal analysis of modelling results in many ways. For demonstration, we present here the calculation results for contamination plume at a moment when peak volumetric activity of I-129 is expected. This is the time approximately 40000 years after the initial moment of release. Yet the initial moment of release will occur 200000 years after the repository closure. Thus, the migration of the most mobile radionuclide ${ }^{129} \mathrm{I}$ in groundwater will be possible only in a very remote future for normal evolution scenario.

Calculation results in the section show that a contamination plume of $10^{-2} \mathrm{~Bq} / \mathrm{l}$ does not reach furher than $700 \mathrm{~m}$ from the defected canister and includes the Cambrian-Vendian and weathered Proterozoic-Archaean aquifers (Fig 8).

Imitation of discharge conditions show that the groundwater containing I-129 with volumetric activity $10^{-5}-10^{-2} \mathrm{~Bq} / \mathrm{l}$ is able to reach a productive well or earth surface.

The areal distribution pattern of volumetric activity of I-129 in the most highly polluted water of ProterozoicArchaean aquifer is given in Fig 9. The highest predicted value of activity near the defected canister in the zone of

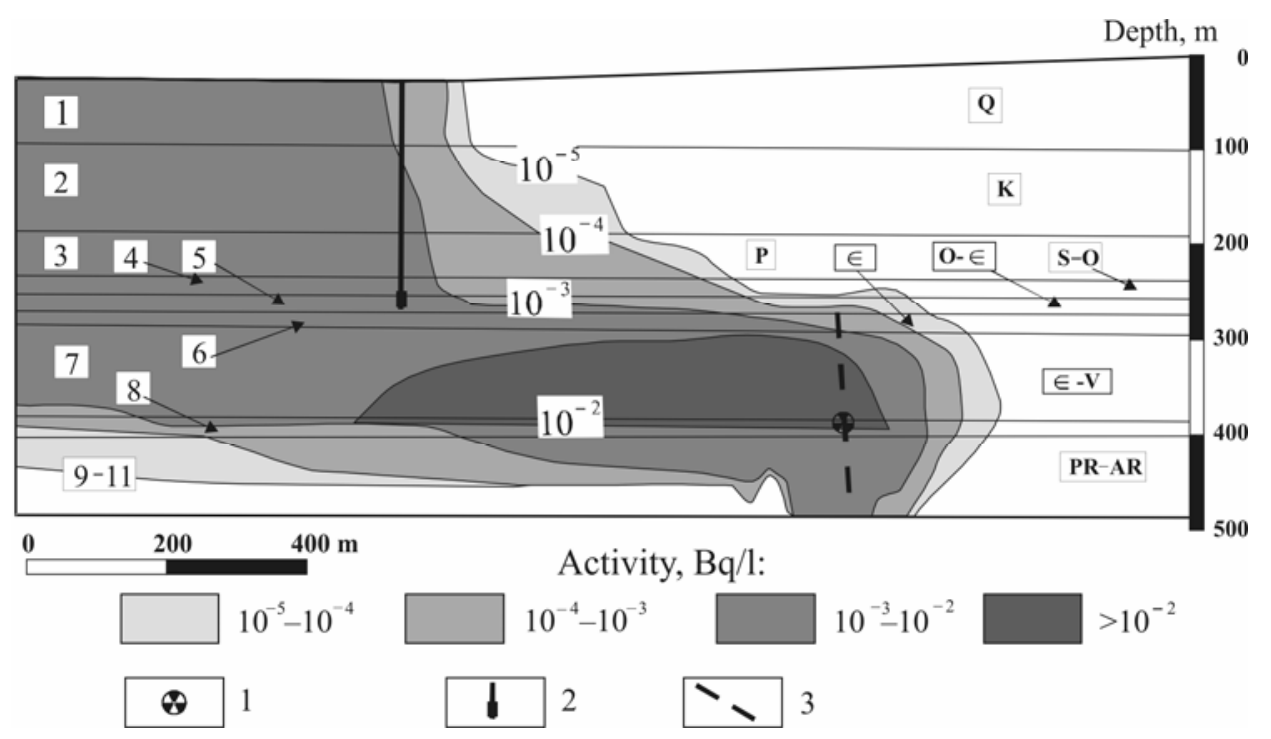

Fig 8. Contamination plume of ${ }^{129} \mathrm{I}$ (cross-section): 1 - repository, 2 - pumping well, 3 - tectonic fault 


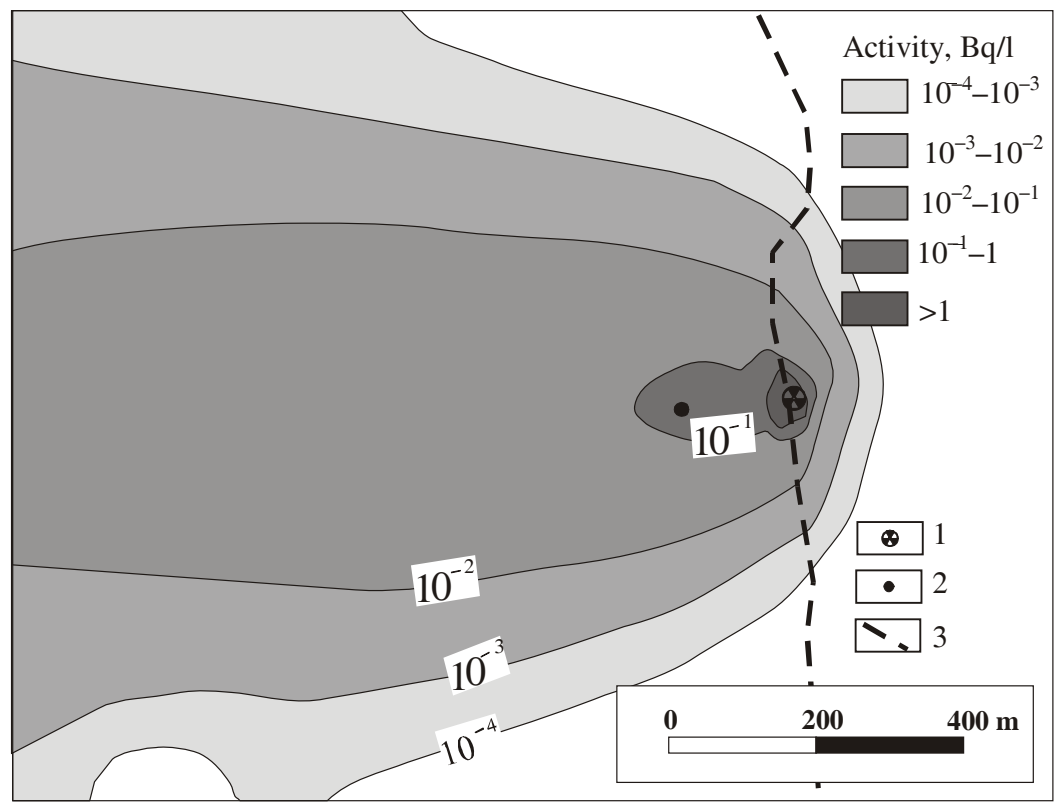

Fig 9. Contamination plume of ${ }^{129} \mathrm{I}$ (areal distribution in Preoterozoic-Archaean aquifer): 1 - repository, 2 - observation point, 3 - tectonic fault

tectonic fault is of the order $1 \mathrm{~Bq} / \mathrm{l}$. Contamination plume of $10^{-1} \mathrm{~Bq} / \mathrm{l}$ reaches the observation point, whereas the groundwater containing I-129 with possible volumetric activity of $10^{-2} \mathrm{~Bq} / \mathrm{l}$ discharges outside the model boundaries in the flow direction.

The highest permissible value of I-129 volumetric activity corresponding to the $0,2 \mathrm{mSv} /$ years effective dose for drinking water pathway is $5,5 \mathrm{~Bq} / \mathrm{l}$. Yet today, for example, the global level of I-129 volumetric activity in the river water is about $10^{-6} \mathrm{~Bq} / \mathrm{l}$.

The numerical model should be improved in future and more scenarios of a long-term evolution of repository-surrounded media should be worked out.

\section{Conclusions}

The crystalline basement is the best worldwide investigated media in connection with disposal of SNF. In Lithuania, thick sedimentary layers of varying origin and properties cover the crystalline basement. Complex structures of overlying layers make performance assessment significantly more sophisticated and complicated.

Modelling of safety of the most relevant radionuclide ${ }^{129} \mathrm{I}$ migration for tectonically fractured domain shows that doses to humans even in such a conservative case will not exceed the existing dose restrictions. Predicted volumetric activity of I-129 at $363 \mathrm{~m}$ distance from repository in groundwater of the Ordovician-Cambrian aquifer, which could be used for water supply, is of the order $10^{-3} \mathrm{~Bq} / \mathrm{l}$.

On the basis of worldwide experience it would in principle be possible to dispose of SNF and other longlived high-level radioactive wastes in a repository built in the crystalline basement.

\section{Acknowledgements}

The Lithuanian State Science and Studies Foundation funded this study within the frame of the program "Research and development in the field of radwaste generation, migration and impact on the environment and human health - RASSA" (contract no. C-19/2004). Partial support was given by RATA. The authors are grateful to Dr S. Motiejūnas from RATA, Prof P. Poškas and PhD student A. Brazauskaite from LEI, R. Kanopienè from LGT, Prof I. Neretnieks, Ass Prof L. Moreno and Dr J. Crawford from Sweden for assistance and co-operation.

Special thanks go to reviewers Prof Dr Habil D. Butkus and Prof Dr Habil P. Vaitiekūnas (VGTU), whose comments resulted in a significantly improved manuscript.

\section{References}

1. IAEA Deep Underground Disposal of Radioactive Waste: Near-Field Effects. Technical reports series No 251, IAEA. Vienna, 1985. $60 \mathrm{p}$.

2. SR97. Deep repository for spent nuclear fuel. SKB Technical Report TR-99-06, Main Report.

3. The scientific and regulatory basis for the geological disposal of radioactive waste. Savage, D. (ed.). Chichester-New York-Brisbane-Toronto-Singapure, 1995.

4. Concept of repository in crystalline rocks. Investigations of possibilities to dispose of spent nuclear fuel in Lithuania: a model case. Vol 2, Vilnius, 2005. 28 p.

5. Generic safety assessment of repository in crystalline rocks. Investigations of possibilities to dispose of spent nuclear fuel in Lithuania: a model case. Vol 3, Vilnius, 2005. $54 \mathrm{p}$.

6. Suitability of geological environment in Lithuania for disposal of spent nuclear fuel. Investigations of possibilities to dispose of spent nuclear fuel in Lithuania: a model case. Vol 1, Vilnius, 2005, p 51-60. 
7. Vieno, T. Safety Analysis of Disposal of Spent Nuclear Fuel. Technical research center of Finland, ESPOO, 1994.

8. KBS-3. Summary report of work done during Basic Design. SKB Report R-04-42, Stockholm, 2004.

9. Dundulis, K.; Gadeikis, S.; Ignatavičius, V. Formation of Engineering Geological Conditions of Quaternary. In: Evolution of Earth Crust and its Resources in Lithuania. Vilnius, 2004, p 320-330 (in Lithuanian).

10. Mikšys, R. B. Formation of Engineering Geological Conditions of Pre-Quaternary. In: Evolution of Earth Crust and its Resources in Lithuania. Vilnius, 2004, p 313-317 (in Lithuanian).

11. Juodkazis, V. Hydrogeology of Baltic Region. Vilnius: Mokslas, 1989 (in Russian).

12. Adam, Ch.; Petschel, M.; Koerner, W. Empfehlungen zur hydrogeologischen Begutachtung der Standorte von Kernanlagen im Rahmen des Strahlenschutz-Genehmigungsverfahrens. In: Staatliches Amt für Atomsicherheit und Strahlenschutz, 1985, p 25-27.

13. De Marsily, G.; Gonçalvès, J.; Violette, S.; Castro, M.-C. Migration mechanisms of radionuclide from a clay repository toward adjacent aquifers and the surface. Applied Physics, 3, 2002, p 945-956.

14. Krishnamoorthy, T. M.; Nair, R. N. Groundwater models for safety analysis of low-level radioactive waste repositories. Nuclear Geophysics, 8, 4, 1994, p 351-360.

15. Chang, S. H.; Cho, W.J. Risk analysis of radioactive waste repository based on the time-dependent hazard rate. Radioactive Waste Management and the Nuclear Fuel Cycle, 5, 1, 1984, p 63-80.
16. Lucero, D. A. Laboratory Column Experiments for Radionuclide Adsorption Studies of the Culebra Dolomite Member of the Rustler Formation SAND97-1763. Sandia National Laboratories, Albuquerque, NM, 1998.

17. Vilks, P.; Caron, F.; Haas, M. K. Potential for the formation and migration of colloidal material from a near surface waste disposal site. Applied Geochemistry, 13, 1998, p 31-42.

18. Ferziger, J. H.; Peric, M. Computational methods for fluid dynamics. Berlin: Springer, 1996.

19. Baker, A. J. Finite element method. In: Johnson R.W. (Editor). The handbook of fluid dynamics, Chapter 28. CRC Press, Springer, 1998.

20. Chavent, G.; Jaffe, J. Mathematical models and finite elements for reservoir simulation. New York, North Holland, 1986.

21. Diersch, H.-J. Reference Manual: Finite Element Subsurface Flow and Transport Simulation System. Wasy Institute for Water Resources Planning and Systems Research Ltd. Berlin, Germany, 2002, p 51-53.

22. Hoteit, H.; Firoozabadi, A. Multicomponent fluid flow by discontinuous Galerkin and mixed methods in unfractured and fractured media. Water Resour. Res., 41 . W11412 (15 p.), doi: 10.1029/2005WR004339. 2005.

23. Samper-Calvete, F. J.; García-Vera, M. A. Inverse modelling of groundwater flow in the semiarid evaporitic closed basin of Los Monegros, Spain. Hydrogeology Journal, Vol 6, No 1, 1998, p 33-49.

\section{POŽEMINIO VANDENS TÉKMIŲ IR RADIONUKLIDŲ PERNAŠOS KRISTALINIAME PAMATE MODELIAVIMAS FEFLOW KODU}

\section{Jakimavičiūtè-Maselienė, J. Mažeika, R. Petrošius}

Santrauka

Pagal radioaktyviujų atliekų tvarkymo strategiją Lietuvoje yra numatoma galimybė panaudotą branduolinị kurą ir ilgaamžes radioaktyviąsias atliekas, susidarančias Ignalinos AE, laidoti giliose geologinèse formacijose. Pradiniai tyrimai 2001-2004 metais buvo skirti atrinkti šiam tikslui tinkamiausias geologines formacijas. Modeliui sudaryti pasirinktas labiausiai ištirtas kristalinis pamatas. Požeminio vandens srauto ir radionuklido (itin mobilaus ir ilgaamžio jodo-129) pernašos modelis buvo sudarytas kompiuterine programa $F E F L O W$, laikantis esminès prielaidos (Švedijos ekspertų pasiūlytas bei Lietuvos energetikos instituto specialistų apskaičiuotas konteinerio defekto scenarijus) bei pagal Pietų Lietuvai būdingas geologines sąlygas ir vyraujančius parametrus $(0,8 \times 0,6 \times 0,52 \mathrm{~km}$ tolimojo lauko blokas). Darbo metu buvo modeliuotas požeminio vandens srautas, kylantis per tektoniškai suardytą zoną, kurioje yra patalpintas pažeistas konteineris. Pagrindiniai skaičiavimų rezultatai: didžiausias ${ }^{129} \mathrm{I}$ tūrinis aktyvumas, kai požeminio vandens srautas, kylantis tektoniškai suardytoje zonoje šalia konteinerio, nesieks $1 \mathrm{~Bq} / \mathrm{l}$, aktyvioje vandens apytakos zonoje - iki $10^{-2} \mathrm{~Bq} / \mathrm{l}$. Rezultatai rodo, kad žmogaus gaunama dozè, jei jis gertu požemini vandeni, neturètų siekti ribinès dozès $(0,2 \mathrm{mSv} / \mathrm{m})$. Modeliavimo darbai, remiantis sudètingesnèmis prielaidomis bei geologinèmis sąlygomis, bus atliekami ateityje.

Prasminiai žodžiai: panaudotas branduolinis kuras, geologinè saugykla, kristalinis pamatas, požeminis vanduo, skaitmeninis modeliavimas, baigtiniai elementai.

\section{МОДЕЛИРОВАНИЕ ПОТОКОВ ПОДЗЕМНЫХ ВОД И ПЕРЕНОСА РАДИОНУКЛИДОВ В КРИСТАЛЛИЧЕСКОМ ФУНДАМЕНТЕ КОМПЬЮТЕРНЫМ КОДОМ FЕFLOW}

\section{В. Якимавичюте-Масялене, Й. Мажейка, Р. Пятрошюс}

\section{P е 3 ю м е}

Стратегия обращения с радиоактивными отходами Литвы в качестве одной из альтернатив предусматривает оценку возможностей захоронения отработанного ядерного топлива и долгоживущих радиоактивных отходов в глубоких геологических формациях. Начальная оценка пригодности всех потенциальных геологических формаций для захоронения отработанного ядерного топлива произведена в Литве в течение 2001-2004 гг. Из-за большого объема существующей разносторонней информации кристаллический фундамент был отобран в первую очередь для моделирования потоков подземных вод и переноса радионуклидов. 
Принимая во внимание главные предпосылки нормального развития (предложенный шведскими экспертами и оцененный экспертами LEI сценарий дефектного канистра с отработанным ядерным топливом) и подобранные параметры, характерные для кристаллического фундамента и вышележащей толщи осадочных пород Южной части Литвы $(0,8 \times 0,6 \times 0,52$-километровый блок дальнего поля), моделировался перенос радионуклидов (йода-129 как мобильного и долгоживущего радионуклида) с потоком подземных вод, используя компьютерный код FEFLOW. Через дефектный канистр, гипотетически расположенный в тектонически нарушенной зоне, средствами моделирования был воссоздан восходящий поток подземных вод.

Главные результаты численного моделирования для очень консервативного случая таковы: при восходящем потоке подземных вод максимум активности I-129 в воде тектонически нарушенной зоны рядом с дефектным канистром не будет превышать 1 Бк/л, а в зоне активного водообмена он близок к $10^{-2}$ Бк/л. Результаты показывают, что получаемые человеком через питьевую воду дозы должны быть меньше ограниченной дозы $\left(0,2 \mathrm{~m}^{3} /\right.$ год).

Ключевые слова: отработанное ядерное топливо, геологическое хранилище, кристаллический фундамент, подземные воды, численное моделирование, конечные элементы.

JAKIMAVIČIŪTĖ-MASELIENĖ Vaidotė. Dr, research worker, Dept of Climate and Water System Research, Institute of Geology and Geography.

Probation: Moscow, Russian Federation; 2002; IAEA fellowship at GSF-Forschungzentrum für Umwelt und Gesundheit GmbH, Institut für Hydrologie, Neuherberg, Germany, 2005; Berlin, Germany, 2005. Publications: author of 10 research papers. Research interests: radionuclide transport within groundwater.

MAŽEIKA Jonas. Dr Habil, head of Dept of Climate and Water System Research and Laboratory for Radioisotope Research, Institute of Geology and Geography.

Probation: technical co-operation projects with IAEA. Publications: author of 60 research papers, 2 monographs. Research interests: environmental radioactivity, radiation protection, isotope hydrology, radionuclide transport in water systems.

PETROŠIUS Rimantas. Dr, senior research worker, Dept of Climate and Water System Research, Institute of Geology and Geography.

Probation: technical co-operation projects with IAEA; Risoe National Laboratory, Denmark, 2000; IAEA, Viena, Austria, 1996. Publications: author of 40 research papers, 2 monographs. Research interests: environmental radioactivity, isotope hydrology, radionuclide transport within groundwater, measurement of radionuclide activity in environmental objects applying liquid scintillation beta spectrometry. 